Journal of Science

and Engineering

Full Paper

\title{
ANALISIS EFESIENSI DAYA PENERANGAN JALAN \\ UMUM TENAGA SURYA DI KECAMATAN PULAU \\ TERNATE
}

Idham A. Djufria ${ }^{*}$, Miftah Muhammad ${ }^{b}$

*Universitas Khairun, Ternate, Indonesia

*Corresponding author idhamadj@gmail.com

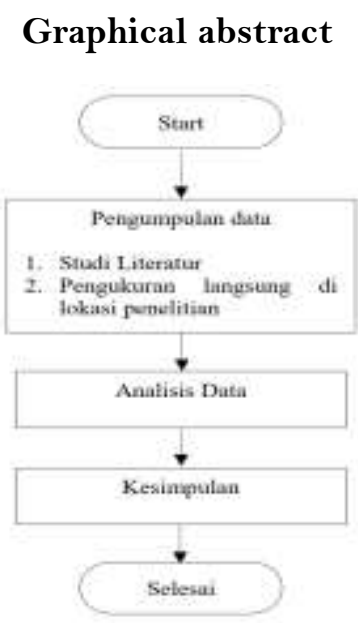

\begin{abstract}
Solar Street Lighting a street lighting solution for areas or areas that are not within the PLN network area or for lighting efficiency using solar power. The use of public street lighting, although it has several advantages, there are still disadvantages in the field conditions, including the improper placement of the lighting so that it is blocked from sunlight, the use of inappropriate materials, unsuitable height of poles and lack of maintenance which results in not optimal utilization of solar energy. In this study, an analysis of the power efficiency of solar street lighting in the District of Ternate Island will be carried out by conducting direct observations and measurements in the field. The results showed that the maximum voltage for street lamps that were not blocked by trees was 23 volts, while those that were blocked by trees were 19 volts. The lighting strength of the street lights that are blocked by trees is 9 lux, while those that are not blocked by trees are 10 lux. The amount of input voltage for the solar panels affects the strength of the lamp lighting

Keywords: Lux, street lighting, solar lighting,
\end{abstract}

\section{Abstrak}

Penerangan Jalan Umum Tenaga Surya (PJUTS) merupakan salah satu solusi penerangan jalan untuk daerah atau kawasan yang tidak berada dalam area jaringan PLN atau untuk efesiensi penerangan dengan menggunakan tenaga surya. Penggunaan Penerangan Jalan Umum meskipun memiliki beberapa kelebihan namun kondisi dilapangan masih terdapat kekurangan diantaranya tidak tepatnya penempatan lampu penerangan sehingga terhalang dari cahaya matahari, pemakaian material yang kurang sesuai, ketinggian tiang yang tidak sesuai serta kurangnya perawatan menyebabkan tidak optimal pemanfaatan energi surya tersebut. Dalam penelitian ini akan dilakukan analisis efesiensi daya lampu penerangan jalan umum tenaga surya di Kecamatan Pulau Ternate dengan melakukan pengamatan dan pengukuran langsung dilapangan. Diperoleh hasil besarnya tegangan maksimum lampu penerangan jalan umum yang tidak terhalang pepohononan adalah sebesaar 23 volt sedangkan yang terhalang pepohonan adalah sebesar 19 volt. kuat pencahayaan pada lampu penerangan jalan yang terhalang pepohonan adalah sebesar 9 lux sedangkan yang tidak terhalang oleh pepohonan sebesar 10 lux. Besarnya tegangan masukan panel surya mempengaruhi kuat pencahayaan lampu.

Kata kunci: Penerangan Jalan, energi surya, lux.

(C) 2021 Penerbit Fakultas Teknik Unkhair. All rights reserved 


\subsection{PENDAHULUAN}

Energi terbarukan merupakan alternatif utama dalam mengatasi ketergantungan negara terhadap energi fosil yang semakin berkurang, disamping itu impor bahan bakar fosil yang mahal semakin memberatkan neraca perdagangan nasional. Pemanfaatan energi baru terbarukan juga merupakan salah satu opsi dalam mengurangi dampak perubahan iklim melalu instalasi panel surya.

Penerangan Jalan Umum Tenaga Surya (PJUTS) merupakan salah satu solusi dari penggunaan penerangan jalan konvensional dalam rangka mengurangi ketergantungan pada energi fosil dan juga ramah lingkungan.

Penggunaan Penerangan Jalan Umum meskipun memiliki beberapa kelebihan namun kondisi dilapangan masih terdapat kekurangan diantaranya tidak tepatnya penempatan lampu penerangan sehingga terhalang dari cahaya matahari, pemakaian material yang kurang sesuai, ketinggian tiang yang tidak sesuai serta kurangnya perawatan menyebabkan tidak optimal pemanfaatan energy surya tersebut.

\subsection{METODE}

Penelitian ini dilakukan untuk mengetahui pengaruh temperature/suhu dan radiasi matahari terhadap tegangan dan daya keluaran panel surya.

Untuk mendapatkan data yang diperlukan dalam penelitian dilakukan pengukuran langsung pada panel surya setiap 1 jam sekali. Dalam penelitian ini digunakan peralatan sebagai berikut :

Tahapan penelitian terbagi atas:

1. Tahap Persiapan;

Melakukan Studi pustaka tentang Penerangan Jalan Umum Tenaga Surya

2. Tahap Pelaksanaan;

Melakukan observasi pada PJU yang sudah terpasang, pelaksanaan pengukuran arus, tegangan dan fluks cahaya pada lokasi pengukuran,

3. Pelaporan

Membuat laporan kemajuan dan laporan akhir hasil dari penelitian.

Lokasi penelitian penelitian akan dilaksanakan di Kecamatan Pulau Ternate..

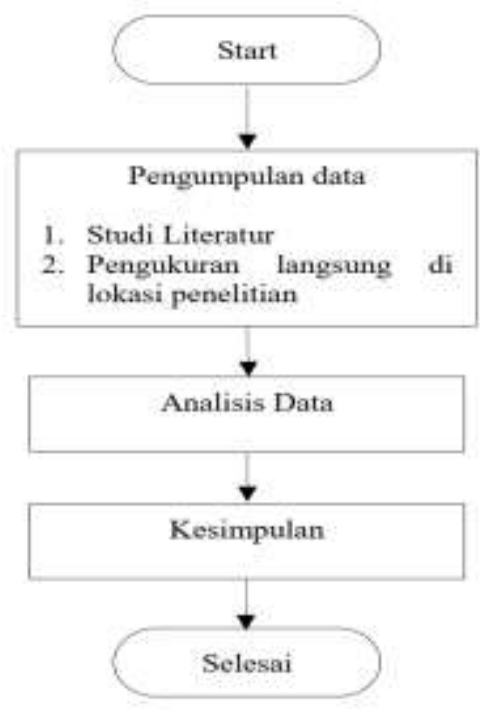

Flow Chart Penelitian

\subsection{HASIL DAN PEMBAHASAN}

\subsection{Data pengukuran}

Data pengukuran dilakukan secara acak pada empat buah tiang PJU yang terdiri dari 2 tiang yang panel suryanya tidak terhalang oleh bayangan maupun pepohonan dan 2 tiang lainnya terhalang oleh bayangan dan tertutup oleh dedaunan. 
Tabel 1. Pengukuran Tegangan dan Arus Pada PJU yang tidak terhalang pepohonan bayangan dan dedaunan

\begin{tabular}{|c|c|c|c|c|c|}
\hline \multicolumn{3}{|c|}{ Tiang 1 } & \multicolumn{3}{c|}{ Tiang 2 } \\
\hline Jam & $\begin{array}{c}\mathbf{V}_{\text {in }} \\
\text { (Volt) }\end{array}$ & $\begin{array}{c}\mathbf{I}_{\text {in }} \\
\text { (Ampere) }\end{array}$ & Jam & $\mathbf{V}_{\text {in }}$ (Volt) & $\begin{array}{c}\mathbf{I}_{\text {in }} \\
\text { (Ampere) }\end{array}$ \\
\hline 08.00 & 12 & 0,1 & 08.00 & 12 & 0,1 \\
\hline 09.00 & 14 & 2,6 & 09.00 & 14 & 2,6 \\
\hline 10.00 & 16 & 3.8 & 10.00 & 17 & 3.8 \\
\hline 11.00 & 17 & 3,9 & 11.00 & 17 & 3,9 \\
\hline 12.00 & 23 & 5.2 & 12.00 & 22 & 4.9 \\
\hline 13.00 & 22 & 4,9 & 13.00 & 22 & 4,9 \\
\hline 14.00 & 16 & 3,7 & 14.00 & 16 & 3,7 \\
\hline 15.00 & 13 & 2,6 & 15.00 & 14 & 2,6 \\
\hline 16.00 & 12 & 2,4 & 16.00 & 13 & 2,4 \\
\hline
\end{tabular}

Pengukuran Lumen :

Pengukuran kuat pencahayaan lampu penerangan jalan umum dilakukan pada malam hari dengan jarak alat ukur dengan permukaan tanah $0.75 \mathrm{~cm}$. Diperoleh nilai kuat pencahayaan sebesar : 10 lux untuk lampu panel Penerangan jalan umum yang tidak terhalang dari bayangan pepohonan dan dedaunan.

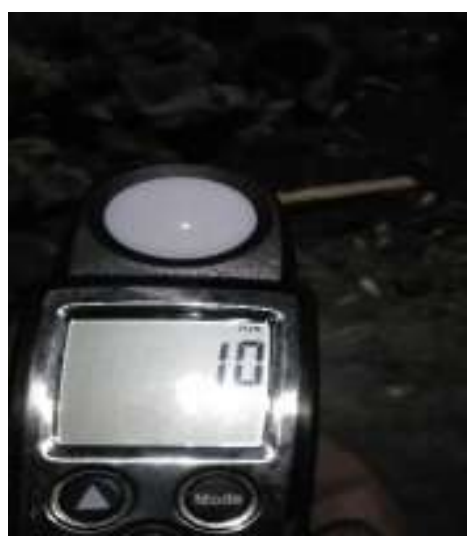

Gambar 1. Pengukuran kuat pencahayaan

Tabel 2. Pengukuran Tegangan dan Arus Pada PJU yang terhalang bayangan pepohonan dan dedaunan

\begin{tabular}{|c|c|c|c|c|c|}
\hline \multicolumn{3}{|c|}{ Tiang 1 } & \multicolumn{3}{c|}{ Tiang 2 } \\
\hline Jam & $\begin{array}{c}\mathbf{V}_{\text {in }} \\
\text { (Volt) }\end{array}$ & $\begin{array}{c}\mathbf{I}_{\text {in }} \\
\text { (Ampere) }\end{array}$ & Jam & $\mathbf{V}_{\text {in }}$ (Volt) & $\begin{array}{c}\mathbf{I}_{\text {in }} \\
\text { (Ampere) }\end{array}$ \\
\hline 08.00 & 12 & 0,1 & 08.00 & 12 & 0,1 \\
\hline 09.00 & 12 & 1,8 & 09.00 & 12 & 1,8 \\
\hline 10.00 & 14 & 2.5 & 10.00 & 14 & 2,5 \\
\hline 11.00 & 15 & 3,2 & 11.00 & 14 & 2,9 \\
\hline 12.00 & 18 & 3.0 & 12.00 & 19 & 3.5 \\
\hline 13.00 & 19 & 3,5 & 13.00 & 19 & 3,5 \\
\hline 14.00 & 17 & 3,7 & 14.00 & 16 & 3,7 \\
\hline 15.00 & 12 & 2,6 & 15.00 & 12 & 2,6 \\
\hline 16.00 & 12 & 2,4 & 16.00 & 12 & 2,4 \\
\hline
\end{tabular}


Pengukuran Lumen :

Pengukuran kuat pencahayaan lampu penerangan jalan umum dilakukan pada malam hari dengan jarak alat ukur dengan permukaan tanah 1 meter. Diperoleh nilai kuat pencahayaan sebesar : 9 lux untuk lampu panel Penerangan jalan umum yang terhalang dari bayangan pepohonan dan dedaunan.

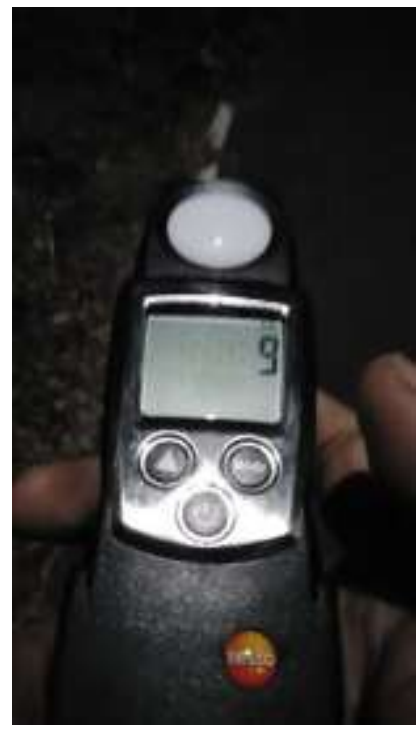

Gambar 2. Pengukuran kuat pencahayaan

Tabel 3. Spesifikasi JPU

\begin{tabular}{|c|c|}
\hline Item Power & LPJU-TS \\
\hline $\begin{array}{ll}\text { - } & \text { Tipe (Type) } \\
\text { - } & \text { Sumber Cahaya (Light Source) } \\
\text { - } & \text { Lumen per watt (Efficacy) } \\
\text { - } & \text { Luminasi Cahaya (Luminous Flux) } \\
\text { - } & \text { Iluminasi Rata-rata (Average Lux) } \\
\text { - } & \text { Tegangan Kerja (Working Voltage) } \\
\text { - } & \text { CRI } \\
\text { - Suhu Kerja (Working Temperature) } & \text { Sudut Pencahayaan (Beam Angle) } \\
\text { - Jumlah LED (Total LED) } \\
\text { - } \quad \text { Pendingin (Cooling) } \\
\text { - } \quad \text { Ukumah Lampu (Case Material) } \\
\text { - } \quad \text { Serat Bersih (Nett Weight) } \\
\text { - Sertifikat (Certificate) }\end{array}$ & 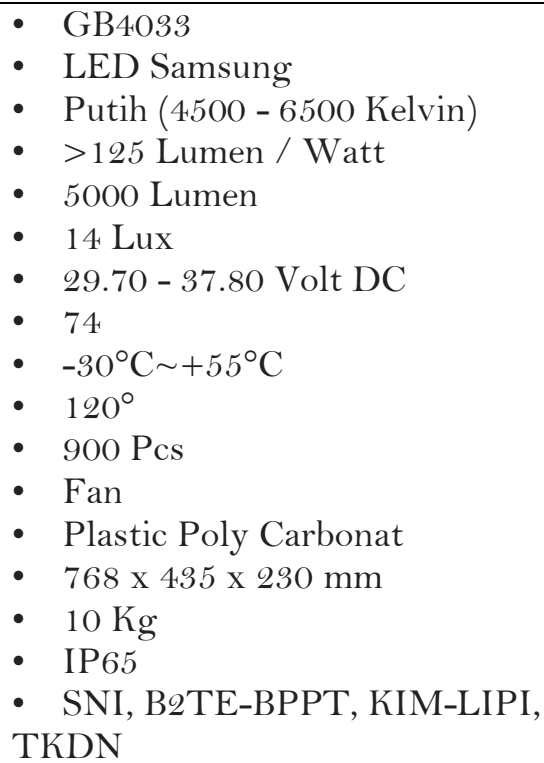 \\
\hline
\end{tabular}



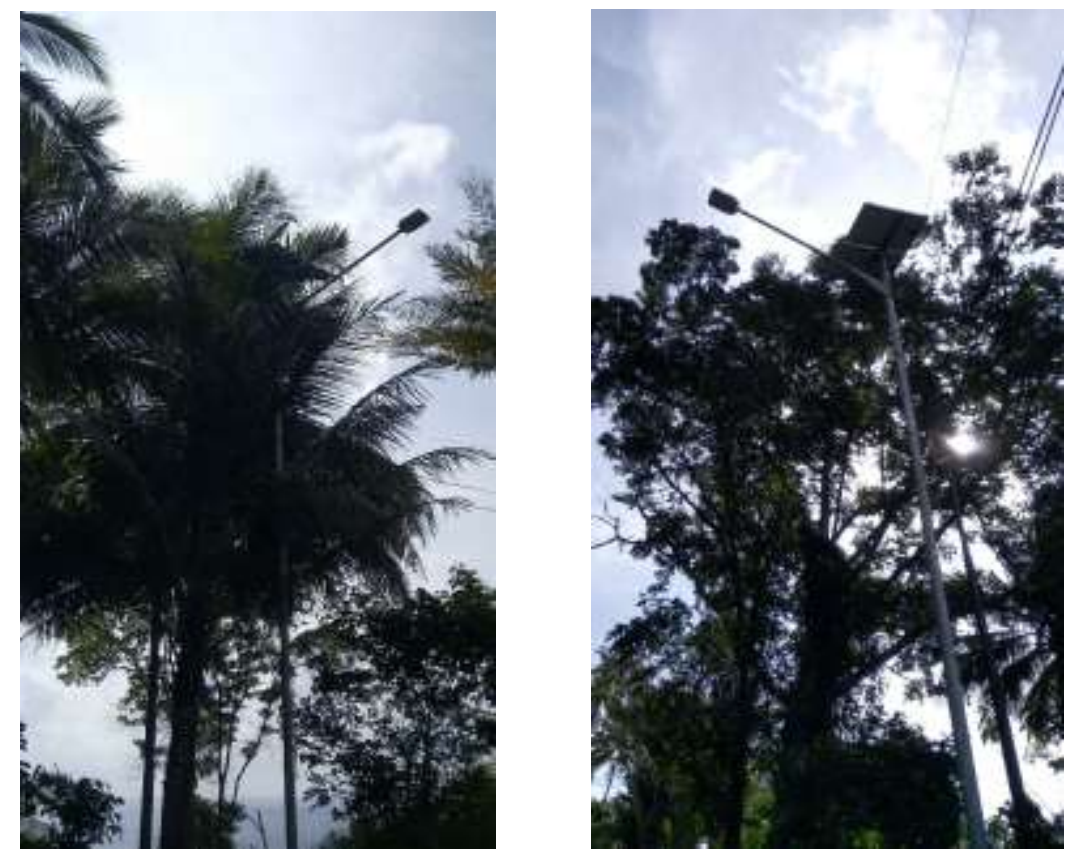

Gambar 3. Lampu PJU yang terhalang dari pepohonan
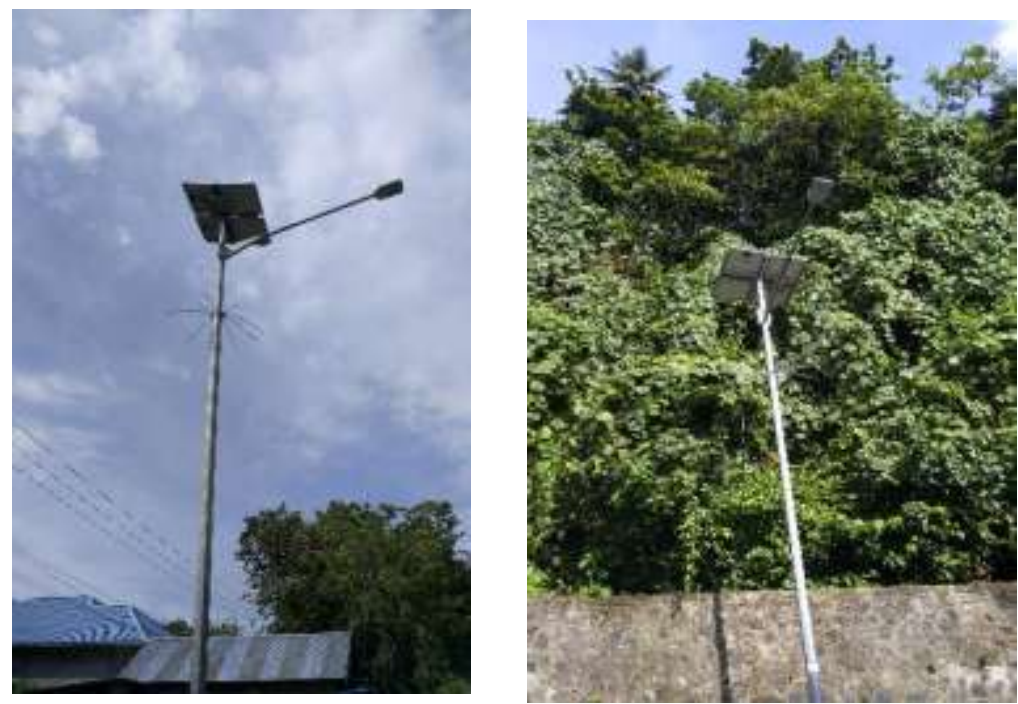

Gambar 3. Lampu PJU yang tidak terhalang pepohonan

\subsection{KESIMPULAN}

Dari hasil analisis data diperoleh kesimpulan bahwa kuat pencahayaan dipengaruhi oleh besarnya tegangan dan arus pada panel surya. Untuk panel surya yang tidak terhalang oleh bayangan pepohonan kuat pencahayaannya sebesar 10 lux, sedangkan kuat pencahayaan pada lampu penerangan jalan umum yang terhalang dari pepohonan dan dedaunan sebesar 9 lux.

\section{Ucapan Terima Kasih}

Penulis mengucapkan Terima Kasih dan Penghargaan setinggi-tingginya kepada Fakultas Teknik yang telah membiayai penelitian ini. 


\section{References}

[1] Angelina Eka Septiana Ginting. 2015. "Studi Metode Rekayasa Nilai pada

[2] Perencanaan LPJU Solar Cell Sebagai Upaya Efisiensi Penggunaan Listrik

[3] di Kota Medan”. Universitas Sumatera UtaraEngga Kusumayogo. 2013. “Analisis Teknis dan Ekonomis Penerapan PJUJapan Lighting Manufactures Association (JLMA). "Kualitas pencahayaan

[4] LED untuk PJU”SNI 7391: 2008 Standar Penerangan Jalan dikawasan Perkotaan

[5] www.panelsurya.com 